San Jose State University

SJSU ScholarWorks

Faculty Publications, Biological Sciences

Biological Sciences

$1-1-2012$

\title{
Little evidence for local adaptation to soils or microclimate in the postfire recruitment of three Californian shrubs
}

\author{
A Bieger \\ Institute of Integrative Biology, Swiss Federal Institute of Technology, ETH Zürich, Zürich, Switzerland \\ N Rajakaruna \\ San Jose State University, nrajakaruna@gmail.com \\ S P. Harrison \\ University of California - Davis
}

Follow this and additional works at: https://scholarworks.sjsu.edu/biol_pub

Part of the Plant Sciences Commons

\section{Recommended Citation}

A Bieger, N Rajakaruna, and S P. Harrison. "Little evidence for local adaptation to soils or microclimate in the postfire recruitment of three Californian shrubs" Plant Ecology and Diversity (2012): 1-33.

https://doi.org/10.1080/17550874.2012.701670

This Article is brought to you for free and open access by the Biological Sciences at SJSU ScholarWorks. It has been accepted for inclusion in Faculty Publications, Biological Sciences by an authorized administrator of SJSU ScholarWorks. For more information, please contact scholarworks@sjsu.edu. 
Postfire recruitment in shrubs

Little evidence for local adaptation to soils or microclimate in the post-fire recruitment of three Californian shrubs

Annette Bieger* ${ }^{1,4}$, Nishanta Rajakaruna ${ }^{2}$ and Susan Harrison ${ }^{3}$

${ }^{1}$ Institute of Integrative Biology, Swiss Federal Institute of Technology, ETH Zürich, Universitätstrasse 16, CH-8092 Zürich, Switzerland;

${ }^{2}$ College of the Atlantic, Bar Harbor, ME 04609, USA; ${ }^{3}$ Department of

Environmental Science and Policy, University of California, 1 Shields Avenue, Davis, CA 95616, USA

*Corresponding author. E-mail: annette.bieger@env.ethz.ch 


\section{ABSTRACT}

Background: Seedling recruitment following fire is an infrequent yet critical demographic transition for woody plants in Mediterranean ecosystems.

Aims: Here we examine whether post-fire seedling recruitment of three widespread Californian chaparral shrubs is affected by local adaptation within an edaphically and topographically complex landscape.

Methods: We reciprocally transplanted 6-month-old seedlings of Adenostema fasciculatum, Ceanothus cuneatus and Eriodictyon californicum to serpentine and sandstone soils, and cool northerly and warm southerly slopes. At the age of two years, none of the species manifested higher survival or growth on 'home' compared to ‘away’ soils or slopes, indicating an absence of local adaptation with respect to seedling recruitment in these environments.

Results: Seedlings of all species manifested lower survival and relative growth on serpentine soils regardless of seedling source, as well as a variety of other destination and source effects.

Conclusions: The ability of these three species to recruit in new environments, such as in restoration settings or in response to shifting climates, is unlikely to be impeded by a need for seeds from sources that closely match their edaphic or topographic destination.

Key words: chaparral; ecotypic differentiation; fire; local adaptation; reciprocal transplant; seedling recruitment; serpentine; topography 


\section{Introduction}

Local adaptation, in which individuals in their 'home' environments show higher fitness than conspecifics from 'away' environments, is of fundamental importance in evolution, ecology, conservation, and restoration (Kawecki and Ebert 2004; Leimu and Fischer 2008; Wright and Stanton 2011). Local adaptation is classically detected using reciprocal transplant experiments, and a recent meta-analysis of such studies found significant local adaptation in $71 \%$ of cases (Leimu and Fischer 2008). Plants may be locally adapted to macroclimate (e.g Turesson 1922; Clausen et al. 1948; Hall et al. 2010) microclimate (Joshi et al. 2001; McKay et al. 2001), salinity (Lowry et al. 2009), or infertile soils such as serpentine (e.g Kruckeberg 1951; O'Dell and Rajakaruna 2011; Wright and Stanton 2011). Local adaptation offers opportunities to study parallel and convergent evolution (Rajakaruna et al. 2003a), the genetic and environmental mechanisms of natural selection (von Wettberg and Wright 2011), and incipient ecological speciation (Kay et al. 2011). Local adaptation is also significant as a possible constraint on the dispersal potential of species within heterogeneous environments. To the extent that seemingly generalist species are actually mosaics of locally adapted genotypes, this may inhibit the potential for ecological restoration (McKay et al. 2005), range shifts under natural and human-caused climate change (Walther et al. 2002; Ackerly 2003; Parmesan 2006), and assisted migration (McLachlan et al. 2007; Aitken et al. 2008).

Local adaptation is expected to be less common in long-lived plants because longevity results in a greater potential for gene flow to homogenize populations (Leimu and Fischer 2008). However, the vast majority of local adaptation studies has been on herbs (including all the 35 cases reviewed by Leimu and Fischer 2008), so the actual frequency of local adaptation in other life forms is not well known. One life- 
history group that has been less studied than others with respect to local adaptation is Mediterranean-climate shrubs that recruit in response to fire (but see Pausas et al. 2012 for a study of local adaptation to fire regime in Ulex parviflorus Pourr.). In Mediterranean shrubland vegetation, fire is a predictable and defining, although usually infrequent event, generally occurring on multi-decadal time scales, but with very large variance in recurrence times (Cody and Mooney 1978; Naveh and Whittaker 1979; Barbour and Minnich 1990). Reproduction by seed for many shrubs occurs primarily or exclusively in the first few growing seasons after a fire, at which time mass germination from the dormant seedbank may be followed by high initial seedling mortality from drought stress during the first several post-fire summers (Jacks 1984; Kummerow et al. 1985; Mills 1986; Moreno et al. 2011). Once adults are established, their mortality and recruitment rates may be low and change in community composition may be relatively modest until the next fire (Keeley and Bond 1997; Keeley et al. 2006; Rutherford et al. 2011; Pérez-Ramos et al. 2012). Years to decades may elapse between fires, with tremendous spatial and temporal variability due to macro- and microclimate, topographic position, vegetation composition and density, and the large element of chance in weather and ignitions. The relative rarity and unpredictability of fire events and the high natural mortality of seedlings make it very challenging to study shrub demography (but see Clemente et al. 1996 for an example), including the role (if any) of local adaptation in shrub recruitment in heterogeneous environments.

We took advantage of a wildfire to test for local adaptation to soil and microclimate in seedlings of three widespread shrubs of Californian chaparral, Adenostema fasciculatum Hook. \& Arn., Ceanothus cuneatus (Hook.) Nutt. and Eriodictyon californicum (Hook. \& Arn) Torr. These were the three most common 
species at our site that met the two necessary criteria for our study: soil generalism and post-fire seeding. Each species is found on serpentine, which is an infertile soil (low Ca:Mg ratio, low primary nutrients, often low water availability, sometimes high levels of Ni and other metals; Kruckeberg 1984) and is often associated with a flora associated with local adaptation, and sandstone, which is nutritionally more balanced and chemically 'normal'. Each species is also found on cool north-facing and warm south-facing slopes. In such 'generalist' chaparral shrubs, individuals growing on serpentine compared to sandstone soils may differ in functionally important morphological traits (e.g. specific leaf area; Anacker et al. 2011) and physiological traits (e.g. water potential, water use-efficiency, nutrient relations; N. Rajakaruna and D. Ackerly, unpublished data); however, to what extent these differences are genetically based is unknown. In pairs of congeneric shrub species that are specialized to either of these soils, the serpentine species often maintain higher foliar Ca:Mg when grown on serpentine, suggesting that the ability to regulate cations at the rootshoot boundary is an important adaptation to serpentine soils (O'Dell et al. 2006; O'Dell and Rajakaruna 2011). These between-soil trait differences provide clear evidence for heterogeneity in the environmental demands faced by 'generalist' chaparral shrubs depending on which soil they grow on. However, to our knowledge no previous studies have investigated the potential for local adaptation to affect the post-fire recruitment of these soil-generalist chaparral shrubs.

Chaparral shrub recruitment is a subject of ever-increasing importance, since the frequency of large and severe fires in North America has increased in recent decades, with a climatic warming playing a detectable role (Gillet and Weaver 2004; Westerling et al. 2006). Increased fire frequency in southern California has contributed to the widespread conversion of chaparral rich in native species to exotic- 
dominated grasslands (Keeley and Foetheringham 2001; Minnich 2001). Chaparral growing on serpentine soils, which has a distinctive mix of endemic and widespread shrub species, tends to burn in a patchier and less intense fashion, but to recover considerably more slowly after fire than non-serpentine chaparral (Safford and Harrison 2004). In a recent study in southern California, chaparral shrubs were found to be dying off at the lower margins of their elevational ranges as predicted under a warming climate; at the same time the upper elevational limits of these shrubs were not expanding (Kelly and Goulden 2008). These impacts on chaparral ecosystems make it timely to examine whether seedling recruitment of common shrubs is constrained by local adaptation in complex landscapes.

\section{Materials and Methods}

\section{Study site and species}

Walker Ridge is a rugged area managed by the U.S. Bureau of Land Management in Lake and Colusa Counties, California, USA (39 05' 09" N / $22^{\circ} 29^{\prime}$ 08" W). Major vegetation types include chaparral dominated by chamise (Adenostema fasciculatum, Rosaceae) on sandstone soils, chaparral dominated by leather oak (Quercus durata Jeps., Fagaceae) on serpentine soils, and several other plant communities not considered in this study [e.g. Quercus douglassi Hook. \& Arn. woodlands on fine-textured sedimentary soils, and Hesperocyparis macnabiana (A. Murray bis) Bartel (Cupressaceae) forests on higher-elevation serpentine soils].

We studied three shrub species that are common in chaparral on both serpentine and sandstone soils and on both north- and south-facing slopes: chamise (Adenostema fasciculatum, Rosaceae), yerba santa (Eriodictyon californicum, Boraginaceae) and buckbrush (Ceanothus cuneatus, Rhamnaceae). They are insect- 
pollinated, and their seed dispersal has not been well characterized, although longdistance seed dispersal is generally considered rare in chaparral shrubs (Minnich and Bahre 1995). A. fasciculatum and C. cuneatus are 'facultative seeders', which are capable of resprouting, but also produce abundant seedlings after fire; E. californicum is an 'obligate seeder' whose mature adults are killed by fire and whose seed very seldom germinates, except in response to fire (Keeley 1991).

The 5867-ha Indian Valley Fire occurred in August 2008 at Walker Ridge, burning large areas on serpentine and non-serpentine soils. Seedlings of our study species appeared in April 2009, simultaneously with the last rains of the year. Newly germinated shrub seedlings thus faced a 'race against time' to develop roots in rapidly drying soils, as is typical in chaparral shrubs (Kummerow et al. 1985).

\section{Experimental set-up}

In late April and early May 2009, we collected newly emerged seedlings from serpentine and sandstone soils, and within each soil, from both north and south aspects with slopes of $21-44 \%$. For each species, we collected 120 seedlings from each of the four source types, for a total of 1440 seedlings. We collected and pooled them from several different locations of each source type over an area of several $\mathrm{km}^{2}$ within the burned area to ensure that the collected seedlings were random with respect to source location. We did not use seedlings showing any visible herbivorous insect damage. The seedlings were collected by carefully shoveling out a block of soil containing their roots, which were generally $2-4 \mathrm{~cm}$ in length with few lateral roots. They were gently shaken to remove dry soil from the roots. To ensure proper drainage, they were then planted into a 50-50 mixture of their home soil and uniform coarse sand in tubular $164 \mathrm{ml}$ pots. The seedlings were kept for 6 months in a shade 
house and transplanted in winter 2009-2010. They were watered two to three times per week. Due to two hot days in Davis and water system failure in August 2009, >50\% of seedlings died in the shade house, leaving 294 A. fasciculatum, 193 C. cuneatus and 154 E. californicum.

Nonetheless, keeping the seedlings in the shade house proved to be a good strategy to hedge against excessive losses of experimental seedlings. In a first trial we transplanted seedlings into the field directly after collection. Over 95\% of them died in the first year, most likely due to rootlet damage that exacerbated drought stress.

For transplantation we chose two replicate destination sites on serpentine and two on sandstone, well interspersed along a 10-km unpaved road traversing the burned area. Sites were chosen by looking for adjacent $\mathrm{N}$ and $\mathrm{S}$ aspects within each soil, with relatively steep slopes (21-44\%), and accessible (50-500 m distant) from the road. Each site consisted of two plots, one on the north and the other on the south slope, for a total of eight destination plots (Table 1).

At each plot we planted up to 96 seedlings (three species $\mathrm{x}$ four sources $\mathrm{x}$ five to eight replicates) at randomly assigned locations in a $10 \mathrm{~m}$ x $12 \mathrm{~m}$ rectangular grid with a spacing of $1 \mathrm{~m}$. We controlled for differences in initial seedling size by randomly assigning seedlings to treatments, as well as by using relative rates as our focal variables (see below). To minimize damage to the roots, which by then were generally 10-15 cm long, the seedlings were transplanted without attempting to wash off the home soil and sand mix. Since we studied these seedlings for 3 years, during which they grew substantially in size and root depth, we believe there is little possibility that their growth was strongly affected by the small amount of original soil mix clinging to the roots at transplantation. Naturally occurring seedlings within a $30 \mathrm{~cm}$ radius around the transplanted seedlings were periodically removed during the first year. 


\section{Measurements}

We monitored seedlings for two years after transplantation. Survival was measured by censusing seedlings every 2 months in the first year and every 6 months in the second year. Seedling height (ground to apex) was measured 3 weeks after transplantation and twice per year thereafter (in spring and autumn). Growth, as relative increase in height, was calculated as ln (final height/initial height).

\section{Survey of natural seedling populations}

To monitor natural (un-transplanted) seedlings, we chose 36, 1 x $1 \mathrm{~m}^{2}$ quadrats adjacent to the transplant sites and at one additional soil/slope combination, each containing at least 15 naturally occurring individuals of one target species (i.e., three species $\mathrm{x}$ four soil/slope combinations $\mathrm{x}$ three replicate sites). For $E$. californicum, 1 x $2 \mathrm{~m}^{2}$ quadrats were sometimes necessary to capture 15 seedlings. We recorded numbers of seedlings and the height of five randomly chosen individuals in these quadrats for three growing seasons (spring 2009-2011).

\section{Habitat conditions}

To confirm the classifications of our sites, we collected soil and temperature data. In each of the eight destination plots we collected two samples of $50 \mathrm{~g}$ soil from 10-30 cm depth in spring 2009. Samples were air dried, ground, and analyzed by A \& L Western Agricultural Laboratories, Modesto, California, for cation exchange capacity, organic matter, $\mathrm{pH}$, exchangeable $\mathrm{K}, \mathrm{Mg}, \mathrm{Zn}, \mathrm{Mn}, \mathrm{Fe}, \mathrm{Cu}, \mathrm{B}, \mathrm{Ca}, \mathrm{S}_{-} \mathrm{SO}_{4}$, $\mathrm{NH}_{4}, \mathrm{Na}, \mathrm{N}$ and Bray P. To quantify the effect of slope and aspect on microclimate, in each destination plot we also measured above- and below-ground temperatures in 
summer 2009. For above-ground measurements we placed temperature loggers (ibuttons, Maxim, Sunnyvale, USA) in white pvc pipes with open ends (pipe length: $150 \mathrm{~mm}$, diameter: $50 \mathrm{~mm}$ ) laid perpendicular to the slope at the upper right and lower left corner of each plot. For below-ground temperature we buried one temperature logger per plot $10 \mathrm{~cm}$ deep in the soil, at the centre of each plot. Temperature was recorded every 2 hours from late June until early September 2009. To evaluate whether our experimental years were typical in terms of key growingseason climatic conditions, we compared 2009 and 2010 values to 26-year means of water-year precipitation (i.e. from fall to spring) and spring and summer temperatures (Table S1). We used climate data for 1986-2011 from the McLaughlin University of California Natural Reserve, located $21 \mathrm{~km}$ south of the study area $\left(38^{\circ} 51^{\prime} \mathrm{N}\right.$, $\left.123^{\circ} 30^{\prime} \mathrm{W}\right)$.

To test for local adaptation with respect to survival, we analysed individual survival curves. We chose the non-parametric Cox proportional hazard model, which uses an unspecified baseline hazard function and depends on the ranks of survival times (Crawley 2007). The model for each species included destination soil (sandstone, serpentine) and destination slope (N, S), source soil (sandstone, serpentine) and source slope (N, S) and their two-way interactions. Site was included as a factor to account for destination-specific differences at the plot level.

The proportion of seedlings surviving in natural populations was analysed using generalized linear models. Due to the non-normal error distribution of the proportion data we used models with binomial error distribution.

To test for local adaptation with respect to growth, we did a multifactorial analysis of variances (ANOVA) with the different source and destination combinations and their two-way interactions as factors. Site was included as a factor 
to account for destination site-specific differences.

All analyses were conducted in R 2.10.1 (R Development Core Team 2007) and survival analyses were made using the package Survival (Therneau and Lumely 2011).

\section{Results}

\section{Survival}

Experimental populations

Survival curves for all three species decreased most on serpentine destination soils regardless of source, and survival for one species (E. californicum) was lower on S-facing than on N-facing destination slopes (Table 2; Figure S1). The survival analysis did not show any significant source-destination interactions indicative of local adaptation (Figure 1; Table 2).

\section{Natural populations}

In naturally occurring seedlings over the same timespan as the experiment, survival was higher on $\mathrm{N}$-facing slopes than on $\mathrm{S}$-facing slopes in A. fasciculatum seedling populations, but only on sandstone soils (GLM with binomial error distribution on proportion: soil-type, $\mathrm{z}=1.4, P=0.15$; aspect, $\mathrm{z}=6.5, P<0.001$; interaction, $\mathrm{z}=-4.1, \mathrm{P}<0.001$; Figure $2 \mathrm{~A}$ ). Percent survival was higher on $\mathrm{N}$-facing than on S-facing slopes in C. cuneatus populations on sandstone soils, and higher on S-facing than on $\mathrm{N}$-facing slopes on serpentine soils (soil, $\mathrm{z}=5.5, P<0.001$; slope, $\mathrm{z}$ $=4.8, P<0.001$; interaction, $\mathrm{z}=-5.9, P<0.001$; Figure $2 \mathrm{~B}$ ). Mean percentage survival was unaffected by soil or slope in E. californicum (soil, z $=-0.9, P=0.3$; slope, $\mathrm{z}=1.1, P=0.3$; interaction, $\mathrm{z}=-0.4, P=0.7$; Figure $2 \mathrm{C}$ ). 


\section{Growth}

\section{Experimental populations}

Initial height of transplanted seedlings measured 3 weeks after they were transplanted in winter 2009/2010, varied significantly among the different source soil and slope combinations for all three species, even though seedlings had been kept under constant conditions in the shade house for more than 6 months. In all three species, seedlings from serpentine sources were significantly smaller compared to those from sandstone sources and seedlings from S-facing slopes were smaller compared to N-facing slopes (Table 3; Figure S2).

Relative height increase in A. fasciculatum and C. cuneatus was smaller for seedlings in serpentine than sandstone destinations, and larger for seedlings from serpentine than sandstone sources (Table 4; Figure 3 A and C). Relative height in A. fasciculatum was larger for seedlings from serpentine sources in sandstone destinations than in seedlings from sandstone sources (Table 4). However, relative height increase never showed any source-destination interactions in a direction indicative of local adaptation (Table 4; Figure 3).

\section{Natural populations}

Seedling height of $A$. fasciculatum and E. californicum in spring 2009 was greater on S-facing than on $\mathrm{N}$-facing slopes, possibly due to earlier germination on the S slopes. However, relative height increase in these species was not influenced by slope. Relative height increase in A. fasciculatum was larger on serpentine than on sandstone soil. Relative height increase in E. californicum was larger on S compared to $\mathrm{N}$ slopes on sandstone, but larger on $\mathrm{N}$ compared to S slopes on serpentine. Initial 
height and height increase in C. cuneatus were relatively little influenced by slope, soil, or their interaction (Table 5; Figure S3).

\section{Habitat characteristics}

Confirming our microclimate classifications, above-ground temperatures (daily maxima) were warmer on S-facing than $\mathrm{N}$-facing slopes, and the S-facing slopes on serpentine were the warmest (Figure S4). Below-ground temperatures showed more muted results, showing highest daily maxima on $\mathrm{N}$-facing serpentine and warmer daily minima on S-facing slopes on both soils (Figure S5). In agreement with the expected differences between serpentine and sandstone soils, serpentine soils at the transplant locations contained significantly less exchangeable Ca (mean serp $=$ $1086 \mathrm{ppm} \pm 133 \mathrm{SE}$, mean sand $=3112 \mathrm{ppm} \pm 708 \mathrm{SE}, P<0.05$ ), more Ni (mean serp $=34.7 \mathrm{ppm} \pm 9.4 \mathrm{SE}$, mean sand $=0.7 \mathrm{ppm} \pm 0.2 \mathrm{SE}, P<0.001)$ and more exchangeable $\mathrm{Mg}$ (mean serp $=2454 \mathrm{ppm} \pm 258$ SE, mean sand $=1124 \mathrm{ppm} \pm 387$ SE, $P<0.05)$ compared to sandstone soils. Exchangeable Ca:Mg was $<<1.0$ on serpentine (mean $=0.48 \pm 0.1 \mathrm{SE})$ and $>>1.0$ on sandstone (mean=3.6 $\pm 0.7 \mathrm{SE}$ ). Soil $\mathrm{pH}$ and organic matter were slightly higher on serpentine than sandstone (Table 1). No differences were found between soils in cation exchange capacity, soluble salts, $\mathrm{SO}_{4}{ }^{2-}, \mathrm{B}, \mathrm{Fe}, \mathrm{Cu}, \mathrm{Mn}, \mathrm{K}, \mathrm{NH}_{4}{ }^{+}$, Na, total $\mathrm{N}$ and Bray P. Nor did any soil properties differ significantly between $\mathrm{N}$ and $\mathrm{S}$ slopes within soil types (MANOVA on $\ln$ transformed data).

Growing-season climatic conditions in 2009 and 2010 were largely typical (i.e., all variables $<1$ SD from their 26-year means), except that spring 2010 mean and maximum temperatures were slightly cooler (1.6 and 1.3 SD below their 26-year means; Table S1). 


\section{Discussion}

Our results reinforce the observation that chaparral shrubs survive and recruit in a challenging fitness landscape. Survival of young seedlings averaged 51-62\% in natural un-manipulated seedlings from a few weeks after germination to an age of 2.5 years (figures that omit additional mortality at earlier stages); moreover, both our experimental transplants and the natural seedlings manifested substantial environmental variation in survival and growth. Survival was up to $60 \%$ lower on serpentine than sandstone soils, and up to $15 \%$ lower on south than north-facing slopes, while relative growth rates were up to $32 \%$ lower on serpentine than sandstone soils. Strong variation in shrub species composition has been observed across soils and slopes in Californian chaparral communities (Franklin 1998, Moody and Meentemeyer 2001, Ackerly et al. 2002), and recruitment differences such as those we observed have the clear potential to contribute to this variation. A. fasciculatum and $C$. cuneatus, for example, are considerably less abundant in serpentine than sandstone chaparral (Harrison 1997), but within sandstone chaparral, both of these species are relatively prevalent across varying slopes, paralleling the strong soil effects and weaker slope effects on the seedling recruitment of these species that we found in this experiment.

Despite the strong direct effects of soils and slopes that we observed, we found no evidence for local adaptation to these environments at the seedling stage in our focal species. The general causes of lack of local adaptation include high gene flow and the absence of fitness trade-offs between environments (Endler 1973; Slatkin 1985). We cannot determine from our results which of the two is more important here. 
In 'bodenvag' species, species that can grow commonly on and also off of serpentine, those showing no evidence for local adaptation have been described as having ‘general-purpose genotypes’ (Kruckeberg 1951). In a recent review, O’Dell and Rajakaruna (2011) found evidence for local adaptation to serpentine in 31 of 35 herbs, but only four of 14 grasses and two of seven trees that have been studied, suggesting that the prevalence of soil generalism is higher in some functional groups than others. Although the specific mechanisms for serpentine-tolerant general-purpose genotypes have not been elucidated, O’Dell and Rajakaruna (2011) speculated that the cell wall structure of grasses makes them less sensitive than forbs to the calcium deficiency of serpentine soils.

Our results do not, of course, rule out local adaptation at either earlier or later life stages than those we were able to study in our experiment. Local adaptation may be more likely to be expressed in reproductive traits, since vegetative traits are so strongly shaped by direct effects of the environment (Nagy and Rice 1997). In the case of local adaptation to serpentine, for example, reduced reproductive effort may arise as a consequence of selection for increased below-ground allocation (Rajakaruna and Bohm 1999; Rajakaruna et al. 2003b). However, Raabová et al. (2007) detected local adaptation in transplanted seeds but not in transplanted adults of a perennial herb, indicating that early life stages may also be important in the expression of local adaptation. In any case, seedling survival is likely to be a highly critical life-history transition for postfire-seeding chaparral shrubs, perhaps exerting larger effects on the distributions of these species than the survival or seed production of mature adults (see Menges 2007 for a discussion of plant demography in the context of fire).

We found differences in seedling heights among the different habitat types in the first weeks after transplantation, even after keeping them in the shade-house for 
more than 6 months, suggesting lasting effects of the maternal and/or early seedling environment. Maternal effects are a well-known problem in studies of local adaptation, especially in long-lived perennials, for which it is seldom practical to grow individuals in a common garden and cross them to obtain F1 seedlings (Wright 2007; Wright and Stanton 2011). A partial solution is to run an experiment long enough so that the effects of maternal environment on offspring phenotype are diminished relative to the lifelong effects of genotype and the current environment (Roach and Wulff 1987; Donohue et al. 2005; Wright et al. 2006); however, this is not an option when studying seedling survival and growth, as in our study. If we had found evidence supporting local adaptation, we would have to consider maternal effects as an alternative explanation; our negative results, however, are unlikely to have been caused by maternal effects. Also, we acknowledge that our statistical power was limited by high seedling mortality. In retrospect, our power to detect relatively small effects would have been strengthened by studying only one species, but this would have also limited the generality of the results.

We conclude that with respect to seedling recruitment, our three focal species are habitat generalists showing no evidence for intraspecific adaptation to soils or slopes. While this may not be particularly surprising, given the relatively fine-grained mosaic of soils and slopes within which they occur, it is a significant negative evidence considering the widespread interest in documenting patterns and mechanisms of local adaptation (Leimu and Fischer 2008; Coop et al. 2010; Anderson et al. 2011). With respect to the accelerating environmental changes affecting Mediterranean shrublands, including increasingly severe droughts, frequent fires, atmospheric nutrient deposition, and habitat conversion, a positive outcome from this study is that successful seedling recruitment of our focal species does not appear to 
depend on close matching between source and destination habitats. 


\section{ACKNOWLEDGEMENTS}

We thank B. Anacker, B. Going, D. Schmidt, E. Dietrich, H. Safford, J. Celis, J.

Strommen, N. Dondoyano, N. Pope, S. Woolhouse, and Y. Thorne for their help in the

field. We thank B. Anacker, B. Going, F. Altermatt, J. Wright and three anonymous reviewers for useful comments on earlier versions of this manuscript. We also thank Paul Aigner and the McLaughlin UC Natural Reserve for providing the long term weather data. This work was supported by National Science Foundation DEB0939403 to N. Rajakaruna. 


\section{References}

Ackerly, D. 2003. Community assembly, niche conservatism, and adaptive evolution in changing environments. International Journal of Plant sciences 164:165184.

Ackerly, D. D., C. A. Knight, S. B. Weiss, K. Barton, and K. P. Starmer. 2002. Leaf size, specific leaf area and microhabitat distribution of chaparral woody plants: contrasting patterns in species level and community level analyses. Oecologia 130:449-457.

Aitken, S. N., S. Yeaman, J. A. Holliday, T. Wang, and S. Curtis-McLane. 2008. Adaptation, migration or extirpation: climate change outcomes for tree populations. Evolutionary Application 1:95-111.

Anacker, B. L., N. Rajakaruna, D. D. Ackerly, M. C. Vasey, S. Harrison, and J. E. Keeley. 2011. Ecological strategies in California chaparral: Interacting effects of soils, climate, and fire on specific leaf area. Plant Ecology \& Diversity 4: 179-188.

Anderson, J. T., J. H. Willis, and T. Mitchell-Olds. 2011. Evolutionary genetics of plant adaptation. Trends in Genetics 27:258-266.

Barbour, M. G. and R. A. Minnich. 1990. The myth of chaparral convergence. Isreal Journal of Botany 39:453-463.

Clausen, J. D., D. Keck, and W. M. Heisey. 1948. Experimental studies on the nature of species. III. Environmental responses of climatic races of Achillea. Carnegie Institution of Washington Publication, Baltimore.

Clemente, A. S., F. C. Rego, and O. A. Correia. 1996. Demographic patterns and productivity of post-fire regeneration in Portuguese Mediterranean Maquis. 
International Journal of Wildland Fire 6:5-12.

Cody, M. L. and H. A. Mooney. 1978. Convergence Versus Nonconvergence in Mediterranean-Climate Ecosystems. Annual Review of Ecology and Systematics 9:265-321.

Coop, G., D. Witonsky, A. Di Rienzo, and J. K. Pritchard. 2010. Using Environmental Correlations to Identify Loci Underlying Local Adaptation. Genetics 185:1411-1423.

Crawley, M. J. 2007. The R Book. Wiley, Imperial College London at Silwood Park, UK.

Donohue, K., L. Dorn, C. Griffith, E. Kim, A. Aguilera, C. R. Polisetty, and J. Schmitt. 2005. The evolutionary ecology of seed germination of Arabidopsis thaliana: variable natural selection on germination timing. Evolution; International Journal of Organic Evolution 59:758-770.

Endler, J. A. 1973. Gene Flow and Population Differentiation. Science 179:243-250. Franklin, J. 1998. Predicting the Distribution of Shrub Species in Southern California from Climate and Terrain-Derived Variables. Journal of Vegetation Science 9:733-748.

Gillet, N. P. and A. J. Weaver. 2004. Detecting the effect of climate change on Canadian forest fires. Geophysical Research Letters 31.

Hall, M. C., D. B. Lowry, and J. H. Willis. 2010. Is local adaptation in Mimulus guttatus caused by trade-offs at individual loci? Molecular Ecology 19:27392753.

Harrison, S. P. 1997. How natural habitat patchiness affects the distribution of diversity in Californian serpentine chaparral. Ecology 78:1898-1906.

Jacks, P. M. 1984. The drought tolerance of Adenostema fasciculatum and Ceanothus 
crassifolius seedlings and vegetation change in the San Gabriel chaparral. San Diego State University, San Diego.

Joshi, J., B. Schmid, M. C. Caldeira, D. P. G., J. Good, R. Harris, A. Hector, K. HussDanell, A. Jumpponen, A. Minns, C. P. H. Mulder, J. S. Pereira, A. Prinz, M. Scherer-Lorenzen, A.-S. D. Siamantziouras, A. C. Terry, A. Y. Troumbis, and J. H. Lawton. 2001. Local adaptation enhances performance of common plant species. Ecology Letters 4:536-544.

Kawecki, T. J. and D. Ebert. 2004. Conceptual issues in local adaptation. Ecology Letters 7:1225-1241.

Kay, K. M., K. L. Ward, L. R. Watt, and D. W. Schemske. 2011. Plant Speciation. Pages 71-95 in S. P. Harrison and N. Rajakaruna, editors. Serpentine: Evolution and Ecology in a Model System. University of California Press, Berkeley.

Keeley, J. E. 1991. Seed Germination and Life History Syndromes in the California Chaparral. The Botanical Review 57:81-116.

Keeley, J. E., C. D. Allen, J. Betancourt, G. W. Chong, C. J. Fotheringham, and H. D. Safford. 2006. A 21st century perspective on postfire seeding. Journal of Forestry 104:1-2.

Keeley, J. E. and W. J. Bond. 1997. Convergent seed germination in South African fynbos and Californian chaparral. Plant Ecology 133:153-167.

Keeley, J. E. and C. J. Foetheringham. 2001. Historic fire regime in southern California shrublands. Conservation Biology 15:1536-1548.

Kelly, A. E. and M. L. Goulden. 2008. Rapid shifts in plant distribution with recent climate change. Proceedings of the National Academy of Sciences USA 105:11823-11826. 
Kruckeberg, A. R. 1951. Intraspecific Variability in the Response of Certain Native Plant Species to Serpentine Soil. American Journal of Botany 38:408-419.

Kruckeberg, A.R. 1984. California serpentines: flora, vegetation, geology, soils and management problems. University of California Press, Berkeley, CA.

Kummerow, J., B. A. Ellis, and J. N. Mills. 1985. Post-fire seedling establishment of Adenostoma fasciculatum and Ceanothus greggii in southern California chaparral. Madrono 32:148-157.

Leimu, R. and M. Fischer. 2008. A meta-analyisis of local adaptation in plants. PLOS one 3:e4010.

Lowry, D. B., M. C. Hall, D. E. Salt, and J. H. Willis. 2009. Genetic and physiological basis of adaptive salt tolerance divergence between coastal and inland Mimulus guttatus. New Phytologist 183:776-788.

McKay, J. K., J. G. Bishop, J. Z. Lin, J. H. Richards, A. Sala, and T. Mitchell-Olds. 2001. Local adaptation across a climatic gradient despite small effective population size in the rare sapphire rockcress. Proceedings of the Royal Society B 268:1715-1721.

McKay, J. K., C. E. Christian, S. Harrison, and K. J. Rice. 2005. “How Local Is Local?"'-A Review of Practical and Conceptual Issues in the Genetics of Restoration. Restoration Ecology 13:432-440.

McLachlan, J., J. Hellman, and M. W. Schwartz. 2007. A Framework of Debate of Assisted Migration in an Era of Climate Change. Conservation Biology 21:297-302.

Menges, E. S. 2007. Integrating demography and fire management: an example from Florida scrub. Australian Journal of Botany 55:261-272.

Mills, J. N. 1986. Herbivores and Early Postfire Succession in Southern California 
Chaparral. Ecology 67:1637-1649.

Minnich, R. A. 2001. An integrated model of two fire regimes. Conservation Biology 15:1549-1553.

Minnich, R. A. and C. J. Bahre. 1995. Wildland fire and chaparral succession along the California Baja-California boundary. International Journal of Wildland Fire 5:13-24.

Moody, A. and R. K. Meentemeyer. 2001. Environmental factors influencing spatial patterns of shrub diversity in chaparral, Santa Ynez Mountains, California. Journal of Vegetation Science 12:41-52.

Moreno, J. M., E. Zuazua, B. Perez, B. Luna, A. Velasco, and V. R. de Dios. 2011. Rainfall patterns after fire differentially affect the recruitment of three Mediterranean shrubs. Biogeosciences 8:3721-3732.

Nagy, E. S. and K. J. Rice. 1997. Local Adaptation in Two Subspecies of an Annual Plant: Implications for Migration and Gene Flow. Evolution; International Journal of Organic Evolution 51:1079-1089.

Naveh, Z. and R. H. Whittaker. 1979. Structural and floristic diversity of shrubland and woodlands in northern Israel and other mediterranean areas. Vegetatio 41:171-190.

O'Dell, R. E., J. J. James, and J. H. Richards. 2006. Congeneric serpentine and nonserpentine shrubs differ more in leaf Ca:Mg than in tolerance of low $\mathrm{N}$, low P, or heavy metals. Plant and Soil 280:49-64.

O'Dell, R. E. and N. Rajakaruna. 2011. Intraspecific variation, adaptation, and evolution. Pages 97-137 in S. P. Harrison and N. Rajakaruna, editors. Serpentine: Evolution and Ecology in a Model System. University of California Press, Berkeley. 
Parmesan, C. 2006. Ecological and Evolutionary Responses to Recent Climate Change. Annual Review of Ecology, Evolution, and Systematics 37:637-669.

Pausas, J. G., G. A. Alessio, B. Moreira, and G. Corcobado. 2012. Fires enhance flammability in Ulex parviflorus. New Phytologist 193:18-23.

Pérez-Ramos, I. M., I. R. Urbieta, M. A. Zavala, and T. Marañón. 2012. Ontogenetic conflicts and rank reversals in two Mediterranean oak species: implications for coexistence. Journal of Ecology 100:467-477.

Raabová, J., Z. Münzbergová, and M. Fischer. 2007. Ecological rather than geographic or genetic distance affects local adaptation of the rare perennial herb, Aster amellus. Biological Conservation 139:348-357.

Rajakaruna, N., B. G. Baldwin, R. Chan, A. M. Desrochers, B. A. Bohm, and J. Whitton. 2003a. Edaphic races and phylogenetic taxa in the Lasthenia californica complex (Asteraceae: Heliantheae): An hypothesis of parallel evolution. Molecular Ecology 12:1675-1679.

Rajakaruna, N., B. G. Baldwin, R. Chan, A. M. Desrochers, B. A. Bohm, and J. Whitton. 2003b. Edaphic races and phylogenetic taxa in the Lasthenia californica complex (Asteraceae: Heliantheae): an hypothesis of parallel evolution. Molecular Ecology 12:1675-1679.

Rajakaruna, N. and B. A. Bohm. 1999. The edaphic factor and patterns of variation in Lasthenia californica (Asteraceae) American Journal of Botany 86:15761596.

Roach, D. A. and R. D. Wulff. 1987. Maternal Effects in Plants. Annual Review of Ecology, Evolution, and Systematics 18:209-235.

Rutherford, M. C., L. W. Powrie, L. B. Husted, and R. C. Turner. 2011. Early postfire plant succession in Peninsula Sandstone Fynbos: The first three years after 
disturbance. South African Journal of Botany 77:665-674.

Safford, H. D. and S. Harrison. 2004. Fire effects on plant diversity in serpentine vs. sandstone chaparral. Ecology 85:539-548.

Slatkin, M. 1985. Gene Flow in Natural Populations. Annual Review of Ecology and Systematics 16:393-430.

R Development Core Team 2007. R: A language and environment for statistical computing. R Foundation for Statistical Computing.

Therneau, T. and originl Splus ->R port by T. Lumley. 2011. Survival: Survival analysis, including penalised likelihood. R package version 2.36-10.

Turesson, G. 1922. The genotypical response of the plant species to the habitat. Hereditas 3:211-350.

von Wettberg, E. J. and J. Wright. 2011. Genomic approaches to understanding adaptation.in S. P. Harrison and N. Rajakaruna, editors. Serpentine: Evolution and Ecology in a Model System. University of California Press, Berkeley.

Walther, G. R., E. Post, P. Convey, A. Menzel, C. Parmesan, T. J. C. Beebee, J. M. Fromentin, O. Hoegh-Guldberg, and F. Bairlein. 2002. Ecological responses to recent climate change. Nature 416:389-395.

Westerling, A. L., H. G. Hidalgo, D. R. Cayan, and T. W. Swetnam. 2006. Warming and earlier spring increase western U.S. Forest wildfire activity. Science 313:940-943.

Wright, J. W. 2007. Local adaptation to serpentine soils in Pinus ponderosa. Plant and Soil 239:209-217.

Wright, J. W. and M. L. Stanton. 2011. Local adaptation in heterogeneous landscapes. Pages 155-179 in S. P. Harrison and N. Rajakaruna, editors. Serpentine: Evolution and Ecology in a Model System. University of California Press, 
Berkeley.

Wright, J. W., M. L. Stanton, and R. Scherson. 2006. Local adaptation to serpentine and non-serpentine soils in Collinsia sparsiflora. Evolutionary Ecology Research 8:1-21. 


\section{NOTES ON CONTRIBUTORS}

Annette Bieger is a project manager and she is interested in processes that affect plant diversity and the spread of invasive species.

Nishanta Rajakaruna is a professor and his research focuses on the factors and mechanisms driving plant speciation and community assembly on serpentine and other edaphically harsh environments.

Susan Harrison is a professor and she studies the processes that shape and maintain plant species diversity at the landscape scale, where small-scale forces such as competition and facilitation interact with large-scale forces such as niche evolution and dispersal. 


\section{Table 1}

Characterisation of the replicated plots at each destination combination. Destination plots were located on serpentine soil (Serp) on north- and south-facing slopes (N, S) and on sandstone soil (Sand) on north- and south-facing slopes (N, S).

\begin{tabular}{|c|c|c|c|c|c|c|c|c|}
\hline \multirow{2}{*}{$\begin{array}{l}\text { Transplant- } \\
\text { destination }\end{array}$} & \multicolumn{2}{|c|}{ Sand N } & \multicolumn{2}{|c|}{ Sand S } & \multicolumn{2}{|c|}{ Serp N } & \multicolumn{2}{|c|}{ Serp S } \\
\hline & 1 & 2 & 1 & 2 & 1 & 2 & 1 & 2 \\
\hline Soiltype & \multicolumn{2}{|c|}{ sandstone } & \multicolumn{2}{|c|}{ sandstone } & \multicolumn{2}{|c|}{ serpentine } & \multicolumn{2}{|c|}{ serpentine } \\
\hline Ca:Mg & 2.6 & 1.3 & 3.9 & 0.7 & 0.4 & 0.4 & 0.2 & 0.5 \\
\hline pH & 6.1 & 6.1 & 7 & 6.5 & 6.8 & 6.7 & 7.1 & 7.1 \\
\hline Org.matter (ENR) & 127 & 110 & 116 & 104 & 193 & 175 & 123 & 148 \\
\hline Slope & $25 \%$ & $21 \%$ & $43 \%$ & $44 \%$ & $27 \%$ & $27 \%$ & $38 \%$ & $37 \%$ \\
\hline Elevation $_{(\mathrm{m})}$ & 840 & 850 & 820 & 850 & 840 & 850 & 850 & 850 \\
\hline
\end{tabular}




\section{Table 2}

Cox proportional survival analysis of transplants over 2 years. Analyses were made for each species separately. In the survival analysis Likelihood ratio-, Wald- and Score (logrank)- test were significant for all three species (A. fasciculatum: $\mathrm{N}=268$, 11 df, $P<0.001$; C. cuneatus: N=175, 11 df, $P<0.001$; E. californicum: $\mathrm{N}=144,11$ df, $P<0.05)$.
A. fasciculatum
C. cuneatus
E. californicum

\begin{tabular}{lcccccc} 
Factor & $\mathbf{z}$ & $\boldsymbol{P}$ & $\mathrm{z}$ & $\boldsymbol{P}$ & $\mathbf{z}$ & $\boldsymbol{P}$ \\
\hline Destination & 3.5 & $<\mathbf{0 . 0 0 1}$ & 4.9 & $<\mathbf{0 . 0 0 1}$ & 2 & $\mathbf{0 . 0 4 5}$ \\
Soil & -1.6 & 0.106 & 1.5 & 0.125 & 2 & $\mathbf{0 . 0 4 0}$ \\
Slope & 0.9 & 0.377 & -2.7 & $\mathbf{0 . 0 0 8}$ & -2 & $\mathbf{0 . 0 5 2}$ \\
Soil x slope & & & & & & \\
Source & -0.3 & 0.767 & -0.3 & 0.743 & 0 & 0.995 \\
Soil & 0.2 & 0.877 & 1.5 & 0.134 & -0.6 & 0.544 \\
Slope & 1.7 & 0.083 & 1.4 & 0.171 & 1.1 & 0.256 \\
Soil x slope & & & & & & \\
Source x destination & -0.6 & 0.561 & 0.2 & 0.837 & 0 & 0.998 \\
Matching source and destination soil & -0.1 & 0.910 & -1.3 & 0.181 & 0.4 & 0.680 \\
Matching source and destination slope & -0.7 & 0.461 & -1.4 & 0.161 & 0.6 & 0.516 \\
Source slope x destination soil & -0.2 & 0.819 & 0.8 & 0.415 & -0.7 & 0.454 \\
Source soil x destination slope & -4.3 & $<\mathbf{0 . 0 0 1}$ & -4.1 & $<\mathbf{0 . 0 0 1}$ & -2.1 & $\mathbf{0 . 0 3 9}$ \\
Site & & & & & & \\
\hline
\end{tabular}




\section{Table 3}

Analysis of variance (ANOVA) on log-transformed initial height of all three species (measured 3 weeks after transplantation) depending on source soil type and slope.

\begin{tabular}{lcccccc}
\hline & \multicolumn{2}{c}{ A. fasciculatum } & \multicolumn{2}{c}{ C. cuneatus } & \multicolumn{2}{c}{ E. californicum } \\
Factor & $\mathbf{F 1 / 2 6 4}$ & $\mathbf{P}$ & $\mathbf{F 1 / 1 7 1}$ & $\mathbf{P}$ & $\mathbf{F 1 / 1 3 8}$ & $\mathbf{P}$ \\
& 48.0 & $<\mathbf{0 . 0 0 1}$ & 89.5 & $<\mathbf{0 . 0 0 1}$ & 11.0 & $\mathbf{0 . 0 0 1}$ \\
Soil & 5.5 & $\mathbf{0 . 0 2 0}$ & 7.4 & $\mathbf{0 . 0 0 7}$ & 4.6 & $\mathbf{0 . 0 3 4}$ \\
Slope & 6.1 & $\mathbf{0 . 0 1 4}$ & 0.3 & 0.558 & 0.9 & 0.358 \\
Soil x slope & & & & & & \\
\end{tabular}




\section{Table 4}

Analyses of variances (ANOVA) of growth (relative increase in height, ln-transformed) in the transplanted seedlings over 2 years. Analyses were done for each species separately.

\begin{tabular}{|c|c|c|c|c|c|c|c|c|c|}
\hline \multirow[b]{2}{*}{ Factor } & \multicolumn{3}{|c|}{ A. fasciculatum } & \multicolumn{3}{|c|}{ C. cuneatus } & \multicolumn{3}{|c|}{ E. californicum } \\
\hline & df & $\mathbf{F}$ & $\mathbf{P}$ & df & $\mathbf{F}$ & $\mathbf{P}$ & df & $\mathbf{F}$ & $\mathbf{P}$ \\
\hline \multicolumn{10}{|l|}{ Destination } \\
\hline Soil & 1 & 24.3 & $<0.001$ & 1 & 5.9 & 0.019 & 1 & 2.3 & 0.140 \\
\hline Slope & 1 & 19.1 & $<0.001$ & 1 & 3.3 & 0.071 & 1 & 0.3 & 0.579 \\
\hline Soil x slope & 1 & 5.3 & 0.022 & 1 & 0.1 & 0.793 & 1 & 0.1 & 0.769 \\
\hline \multicolumn{10}{|l|}{ Source } \\
\hline Soil & 1 & 19.5 & $<0.001$ & 1 & 23.2 & $<0.001$ & 1 & 0 & 0.903 \\
\hline Slope & 1 & 1.8 & 0.187 & 1 & 1.1 & 0.292 & 1 & 3.1 & 0.086 \\
\hline Soil x slope & 1 & 0.7 & 0.398 & 1 & 0.3 & 0.594 & 1 & 1.1 & 0.299 \\
\hline \multicolumn{10}{|l|}{ Source $\mathrm{x}$ destination } \\
\hline $\begin{array}{l}\text { Matching source and } \\
\text { destination soil }\end{array}$ & 1 & 0 & 0.907 & 1 & 0.4 & 0.521 & 1 & 2.9 & 0.098 \\
\hline $\begin{array}{l}\text { Matching source and } \\
\text { destination slope }\end{array}$ & 1 & 3.2 & 0.078 & 1 & 0.7 & 0.391 & 1 & 0.3 & 0.594 \\
\hline Source slope $\mathrm{x}$ destination soil & 1 & 0.6 & 0.446 & 1 & 3.3 & 0.073 & 1 & 2.3 & 0.136 \\
\hline Source soil $\mathrm{x}$ destination slope & 1 & 0.1 & 0.736 & 1 & 0.5 & 0.504 & 1 & 0.2 & 0.696 \\
\hline Site & 1 & 2.4 & 0.120 & 1 & 2.1 & 0.154 & 1 & 0.9 & 0.343 \\
\hline Residuals & 179 & & & 75 & & & 46 & & \\
\hline
\end{tabular}


Bieger, Rajakaruna and Harrison

\section{Table 5}

Analysis of variance (ANOVA) for initial height and growth (relative height increase: final/initial height) over 2 years of natural seedling populations.

Initial height

A. fasciculatum

C. cuneatus

E. californicum

\begin{tabular}{lcccccc}
\hline Factor & F1/56 & $\mathbf{P}$ & $\mathbf{F 1 / 5 6}$ & $\mathbf{P}$ & $\mathbf{F 1 / 5 6}$ & $\mathbf{P}$ \\
\hline & & & & & & \\
Soil & 9.4 & $\mathbf{0 . 0 0 3}$ & 3.6 & 0.065 & 1.7 & 0.196 \\
Slope & 6.3 & $\mathbf{0 . 0 1 5}$ & 0.5 & 0.491 & 8.4 & $\mathbf{0 . 0 0 5}$ \\
Soil x slope & 0.0 & 0.846 & 0.3 & 0.607 & 0.1 & 0.785 \\
\hline
\end{tabular}

Growth

\begin{tabular}{lcccccc}
\hline Factor & F1/56 & $\mathbf{P}$ & $\mathbf{F 1 / 5 6}$ & $\mathbf{P}$ & $\mathbf{F 1 / 5 6}$ & $\mathbf{P}$ \\
\hline & & & & & & \\
Soil & 8.5 & $\mathbf{0 . 0 0 5}$ & 0.0 & 0.979 & 3.6 & 0.063 \\
Slope & 0.2 & 0.662 & 1.1 & 0.295 & 2.6 & 0.112 \\
Soil x slope & 0.9 & 0.340 & 1.6 & 0.211 & 7.6 & $\mathbf{0 . 0 0 8}$
\end{tabular}




\section{Figure 1}

Mean percent survival ( \pm SE) over replicated experimental populations for $A$. fasciculatum (A, B), C. cuneatus (C, D) and E. californicum (E, F). Percent seedlings surviving per source and destination combination was calculated by dividing the number of surviving seedlings after 2 years with the number of initially transplanted seedlings. The panels A, C and E show survival depending on source and destination soil-type. The panels B, D and F show survival depending on source and destination slope.

\section{Figure 2}

Mean percent survival $( \pm \mathrm{SE}$ ) of replicated natural populations of $A$. fasciculatum (A), $C$. cuneatus (B), and E. californicum (C). Densities of naturally emerged seedling populations were censused over three growing seasons (starting at the time of seedling collection for the transplant experiment) and survival was calculated by dividing final with initial density. Survival on sandstone north- and south-facing slopes and serpentine, respectively, are shown.

\section{Figure 3}

Mean relative growth rates $( \pm \mathrm{SE}$ ) over 16 months over replicated experimental populations of A. fasciculatum (A, D), C. cuneatus (B, E) and E. californicum (C, F). The panels show soil effects (A, B, and C) and slope effects (D, E, F). Relative growth rates were lntransformed and calculated dividing final with initial height. 